\begin{abstract}
Joseph A. Clougherty *
Industry Trade-Balance and Domestic Merger

Policy: Some Empirical Evidence from the U.S.
\end{abstract}

* Tilburg University

SP II 2003-19

November 2003

ISSN Nr. $0722-6748$

Research Area

Markets and Political Economy

Research Unit

Competitiveness and Industrial Change
Forschungsschwerpunkt

Markt und politische Ökonomie

Abteilung

Wettbewerbsfähigkeit und industrieller Wandel 
Zitierweise/Citation:

Joseph A. Clougherty, Industry Trade-Balance and

Domestic Merger Policy: Some Empirical Evidence from

the U.S., Discussion Paper SP II 2003 - 19,

Wissenschaftszentrum Berlin, 2003.

Wissenschaftszentrum Berlin für Sozialforschung $\mathrm{gGmbH}$,

Reichpietschufer 50, 10785 Berlin, Germany, Tel. (030) 25491 - 0

Internet: www.wz-berlin.de 


\section{ABSTRACT \\ Industry Trade-Balance and Domestic Merger Policy: Some Empirical Evidence from the U.S.}

by Joseph A. Clougherty

The literature on antitrust in an open-economy setting is inconclusive with respect to the role played by trade-balance on the tenor of domestic merger policy. Using a panel data set composed of US merger reviews by industrial sector over the 1997-2001 period, I empirically test the impact of sectoral trade balance on the level of antitrust scrutiny. The results suggest that larger trade balances lead to more vigorous antitrust scrutiny; thus, 'strategic' merger policy does not appear evident, and consumer-surplus appears to guide US merger policy even under the lure of international competitive gains.

Keywords: Merger Policy, International Effects, Open Economy

JEL Classification: L40, LOO, L40

ZUSAMMENFASSUNG

\section{Empirische Evidenz über den Zusammenhang von Leistungsbilanz und Fusionspolitik in den U.S.A.}

Die ,anti-trust'-Literatur bezogen auf eine offene Volkswirtschaft sagt wenig dazu aus, welche Rolle die Leistungsbilanz für die Fusionspolitik eines Landes spielt. In diesem Papier wird anhand von Paneldaten, in denen die Berichte der Fusionskontrolle in unterschiedlichen Industrien der U.S.A. über einen Zeitraum von 1997-2001 zusammengestellt sind, empirisch getestet, welchen Effekt die Leistungsbilanzen - nach Industriezweigen unterteilt - auf das Niveau der ,antitrust'-Kontrolle haben. Die Ergebnisse der Tests deuten an, dass mit größerem Leistungsbilanzgewicht auch eine strengere ,anti-trust'-Kontrolle einhergeht. Folglich ist eine ,strategische' Fusionspolitik der U.S.A. nicht zu erkennen. Stattdessen scheint die US-amerikanische Fusionspolitik stark vom Verbrauchernutzen geleitet $\mathrm{zu}$ sein, trotz der Verheißung internationaler Wettbewerbsvorteile. 


\section{Introduction}

A voluminous literature (e.g., Williamson, 1968; Fisher, 1987; White, 1987; Farrell \& Shapiro, 1990) exists considering the welfare effect of mergers involving only domestic competitive implications: i.e., domestic merger activity within a closed economy. Globalization, however, is fast fictionalizing the notion that a merger-even one with the acquirer and target firm headquartered in the same nation — can be completely embedded within one nation (Melamed, 2000). Accordingly, the intersection between trade and competition policy-a previously neglected topic_-has recently received a great deal of scholarly attention (e.g., Richardson, 1999; Vandenbussche, 2000; Horn \& Levinsohn, 2001). Further, and closer to the topic at hand, a growing dialogue exists on the design of merger policy in an open economy setting (e.g., Barros \& Cabral, 1994; Levinsohn, 1997; Head \& Ries, 1997; Neven \& Roller, 2000a, 2000b; Mavrodis \& Neven, 2001; Zhang \& Chen, 2002). Such debate is particularly healthy as the globalization of mergers and acquisitions suggests that larger nations with commitments to antitrust (e.g., the U.S.) will increasingly face the dilemmas previously experienced by mid-sized nations with commitments to antitrust (e.g., the U.K. \& Germany).

The question motivating this work is how does industry trade-balance (a net-exporter or net-importer profile) impact the tenor of merger policy for a specific industry sector. Within the above dialogue on merger policy in an open economy setting exists a sub-literature that specifically considers the impact of industry trade balance on optimal domestic merger policy. Invoking various oligopolistic scenarios, Barros \& Cabral (1994), Levinsohn (1997), Sorgard (1997), Head \& Ries (1997), Yano (2001) and Zhang \& Chen (2002)—all find positive (negative) trade balances to conditionally favor more lenient (strict) domestic merger policy. Explicit in all these works is that antitrust agencies face a national-welfare criterion of which foreign producers and consumers are not part. However, Neven and Roller (2000a, 2000b) note 
that consumer-surplus (not national-welfare) is the stated criterion for many antitrust agencies, and further show little scope for conflict when regulators maximize that objective function. Additionally, Landes and Posner (1981), Ghosal (2002) and others make the intuitive argument that imports ameliorate anticompetitive behavior in domestic markets. Thus suggesting the converse of above: positive (negative) trade balances conditionally favor more strict (lenient) domestic merger policy. Such discord is made more problematic once one recognizes the political economic nature of antitrust, the dangers of using 'strategic' merger policy, and the bureaucratic discretion held by most antitrust authorities.

It remains difficult then to theoretically predict how trade balance impacts the tenor of domestic merger policy. Solving how—and whether — an industry trade profile (net-exporter/netimporter) alters domestic merger policy is ultimately an empirical question. Consequently, I test here the impact of trade-balance on merger-policy outcomes in the various US industrial sectors. A comprehensive panel data set—covering US (both FTC \& DOJ) merger policy at the two-digit SIC code over the 1997-2001 period-allows testing whether trade-balance acts to promote strict or lenient merger policy. The empirical results tentatively support higher trade balances leading to stricter merger policy.

The paper is organized as follows to support the analysis. Section 2 reviews the competing theories on how trade-balance might impact the nature of domestic merger policy and formulates two competing propositions that motivate the empirical testing. Section 3 presents the results of the empirical tests. Section 4 concludes.

\section{Theories and Competing Proposition Formulation}

Barros and Cabral (1994) sparked the sub-literature on trade balance and the optimal tenor of domestic merger policy in an open-economy setting with their extension of Farrell and 
Shapiro's (1990) pioneering approach to mergers in a closed-economy. The Barros and Cabral set-up consequently conforms rather closely to that of Farrell and Shapiro in a number of dimensions. First, the adoption of Farrell and Shapiro's external-effect decision criterion where mergers are assumed to be profitable for the merging parties; hence, a positive net impact on non-merging parties (non-merging home firms and home consumers) is a sufficient condition for supporting a merger. Second, the employment of Farrell and Shapiro's innovative infinitesimal method: a technique consisting of defining the effect of a merger as the sum of many infinitesimal price increases which allows capturing the merger effect by investigating the impact of an infinitesimal price increase and specifying sufficiency conditions for the sign of the marginal price increase to be valid.

In extending the Farrell and Shapiro (1990) set-up, however, Barros and Cabral (1994) find a somewhat counterintuitive result: the more foreign competition faced by a national economy, the less likely will a domestic merger enhance national welfare. Recall that under Farrell and Shapiro (1990) a positive external effect keys on the increased profitability of nonmerging firms; yet, Barros and Cabral (1994) point out that when non-merging firms are mostly foreign (e.g., in a net-importer industry) then the external effect is more likely to be negative. The converse is true for exporting economies: in this case, the positive external effect is more readily satisfied, as the profit gains of domestic firms are more likely to outweigh domestic consumer losses. Consequently, net-exporter nations reap the majority of a merger's positive effects, while net-importer nations reap the majority of the merger's negative effects.

Sorgard's (1997) study follows closely Barros and Cabral's work (adopting the infinitesimal method, the lack of merger synergies and post-merger price increases), but discards the external-effect criterion for a national-welfare criterion. Sorgard points out that a priceincreasing merger in a net-importer nation will unambiguously harm home-nation welfare, as the 
deadweight loss and increased import expenditures go unmitigated. Conversely, domestic mergers in a net-exporter nation can enhance home-nation welfare when the price-cost margin from the world market is greater than that in the domestic market; i.e., less competitive foreign firms favor a domestic merger improving home-nation welfare.

Zhang and Chen (2002) take a different approach and consider the presence of scale economies for domestic mergers in an open economy setting. They extend Krugman's (1984) work on the ability of trade policy to promote exports by allowing competition policy to also promote exports. Zhang and Chen thus find that domestic mergers in exporter industries more readily improve home-nation welfare due to the shift in oligopolistic rents from foreign to home producers. They further observe that exports lower the critical economies-of-scale value necessary for permitting a domestic merger: i.e., when domestic mergers result in enhanced international rents, then less merger synergies are required for home-nation welfare enhancement.

Even, Head and Ries (1997)—who argue that the prevailing antitrust authorities will block non-synergistic domestic mergers which reduce world welfare-find a net-exporter dynamic in their model of decentralized merger regulation, as national-welfare maximizing authorities can not be trusted with synergistic domestic mergers which reduce world welfare. Head and Ries state "a home country government is less likely to approve a merger if the merging firms' rivals are owned by foreigners" (1997: 1119). Further, two additional studies (Levinsohn, 1997; Yano, 2001) that take even more varied modeling decisions also find domestic mergers more readily improving home-nation welfare under net-exporter status.

In sum, the above studies cover a number of different cases-a necessity when it comes to oligopolistic market structures-yet all the studies contain a clear and common contention concerning the relationship between a national industry's trade-balance and optimal merger 
policy. The common intuition behind the studies runs along the following lines: national welfare — with the typical producer-gains/consumer-losses tradeoff—is the ultimate criterion for domestic merger reviews (even Barros \& Cabral's (1994) approach is meant as a short-cut to national welfare), and in an open-economy setting home producer gains are more (less) likely to outweigh any potential home consumer losses when an industry is characterized by net-exporter (net-importer) status. Put differently, the producer-gain/consumer-loss tradeoff begins to vanish when the consumers involved are foreign; instead, the search for international rents guides policy (Levinsohn, 1997). Consequently, antitrust officials face a national welfare incentive to practice lax reviews of domestic mergers in net-exporter industries and strict reviews in net-importer industries. The following proposition captures the public policy implications of the above literature stream:

Proposition A: Greater (lesser) trade-balances for a national industry sector favor more lenient (strict) reviews of domestic merger activity under nationalwelfare maximizing antitrust objectives.

Many antitrust officials (particularly from the EU and US) are loath to engage in any discussion of antitrust rationales that contain national-champion foundations (even if confined to net-exporter industries); though, a read through the OECD (1998) annual reports on member nation competition policies indicates this discretion is not universally shared. The main argument often used to counter any national rent-seeking notions is that national-welfare is simply not the criterion used for merger decisions. Neven and Roller (2000a, 2000b) point out that the stated objective of many antitrust agencies (including the US and EU) is the promotion of consumersurplus and not national-welfare. For example Mario Monti, European Commissioner for Competition, recently reiterated that the Competition Directorate General's "ultimate policy goal is the protection of consumer welfare" (Monti, 2002: 71). Neven and Roller (2000a, 2000b) go 
on to show that if antitrust officials strive to fulfill these goals, then there is little scope for conflict between antitrust jurisdictions.

If consumer-surplus guides merger reviews, then the policy recommendations summarized by Proposition A are reversed to recommendations that appear far more intuitive from an economist's perspective: i.e., foreign competition and imports play a more healthy role vis-à-vis domestic merger reviews. A number of scholars (e.g., Landes \& Posner, 1981; Abbot, 1985; Ghosal, 2002) have argued that foreign production involves important domestic antitrust implications. High imports imply broader geographic markets, dilute concerns over high domestic concentration and--via the substitutability of foreign for domestic goods--lessen antitrust anxieties with regard to domestic merger activity. In order to fully factor this more intuitive link between net-exporter/net-importer status and the tenor of domestic merger reviews, two effects must be considered.

First, import levels (which negatively affect trade balance) involve an obvious disciplinary effect in terms of domestic concentration. For instance, if antitrust officials excluded foreign competition from a competitive analysis then domestic concentration levels would likely overstate market power. Abbott (1985) illustrates the importance of factoring foreign competition in the form of imports into any sound estimation of domestic market concentration and market power. A strong import presence (reflected by a net-importer industry) reduces the potential harm to home consumers from a domestic merger. However, if a national industry is characterized by a net-exporter status, then it is less feasible to consider foreign firms as playing a mitigating role in terms of domestic anti-competitive behavior: i.e., the more a nation is a netexporter, the less likely will foreign firms help ameliorate anticompetitive behavior on the part of domestic firms. Consequently, the more a national industry is characterized by a net-importer 
(net-exporter) status, the more (less) foreign competitors discipline domestic market power and guard domestic consumer-surplus.

Second, the ability of foreign firms to divert output relatively quickly to increases in the price-cost markups in domestic markets represents an additional discipline-beyond the absolute level of foreign imports - to anticompetitive behavior on the part of domestic firms (Landes \& Posner, 1981). Yet, foreign competitors are often discounted when it comes to defining domestic market concentration and market power, as domestic supply is deemed better able to constrain market power than foreign supply (Ordover \& Willig, 1983; U.S. DOJ, 1997). The reasoning behind this assumption is that the ability of foreign firms to respond quickly to a drop in domestic production is constrained. Landes and Posner (1981) contend that the ability of foreign producers to divert products quickly to a domestic market undergoing post-merger competitivesoftening depends on the previous crossing of certain thresholds. Ghosal (2002) identifies three particular threshold domains: 1) foreign firms will need to have previously overcome trade and entry barriers; 2) foreign firms will need to have previously overcome distribution and advertising barriers; 3) foreign production costs will need to be relatively low in order to offset tariffs and transport costs. Note that the more a domestic industry is characterized by netimporter status, the more these qualifications have previously been overcome: i.e., net-importer status suggests that trade-entry-distribution-advertising barriers have been overcome, and that foreign firms have superior efficiency relative to domestic firms. Consequently, the more a nation is a net-importer, the more foreign supply acts as a 'full' source of market discipline for anticompetitive domestic practices.

The following proposition captures the gist of the public policy implications suggested by the above discussion: 
Proposition B: Greater (lesser) trade-balances for a national industry sector favor more strict (lenient) reviews of domestic merger activity under consumersurplus maximizing antitrust objectives.

Propositions A and B seemingly reduce to whether a nation targets national-welfare or consumer-surplus as the objective function for merger policy; thus, suggesting that empirical tests—as proposed and conducted here—might be a trivial exercise. Yet such an abstraction suffers from three detractions: 1) the opening up of antitrust to political economic determinants; 2) the dangers of engaging in 'strategic' merger policy; 3) the bureaucratic discretion held by antitrust officials.

First off, the analysis until this point has taken an implicit 'public interest' approach to explaining antitrust outcomes; yet, a number of scholars (Pittman, 1977; Faith, Leavens \& Tollison, 1982; Coate, Higgins \& McChesney, 1990; Clougherty, 2002) consider antitrust outcomes to be—at least partially—subject to political pressure. For instance, Neven, Papandropoulos and Seabright (1998) find that firms experiencing difficult antitrust reviews tend to engage in greater lobbying activity vis-à-vis the European Commission. Further, Neven and Roller (2000) hypothesize that consumer-surplus standards may be optimal in the sense that producer-surplus (the other element of a national-welfare analysis) will express itself via the political process (note also that consumer-interests suffer from an obvious collective action handicap). Thus under the case of a consumer-surplus maximizing antitrust authority, the additional producer gains reaped by home producers in post-merger international markets would enhance the incentive for merging firms to up their lobbying efforts in order to secure antitrust approval (Clougherty, 2002). Consequently, antitrust authorities adopting a consumer-surplus merger criterion may still practice more lax merger reviews when national industries are characterized as net-exporters; though, in this case the impetus for such lax policies derivates 
from the enhanced political pressure of domestic producers, as opposed to a 'public interest' calculation.

Second, consider a national antitrust authority that adopts a national-welfare objective for merger reviews. Even in this case, practicing lax antitrust for net-export industries might suffer from many of the same objections—retaliation (Grossman, 1990), minimal actual gains (Krugman \& Smith, 1994), the nature of oligopolistic competition (Eaton \& Grossman, 1986), and the bidding up of domestic cost structures (Dixit \& Grossman, 1984)—leveled at the strategic trade literature. Recall that Zhang and Chen (2002) consider the rationale to be lax with mergers in net-exporter industries as akin to Krugman's (1984) rationale for providing subsidies; essentially, lax merger reviews are a substitute for a strategic subsidy. Accordingly, practicing strategic merger policy might ultimately reduce national welfare; hence, engaging in such a policy might not truly maximize national welfare and thus might not be followed.

Lastly, the stated objectives of antitrust agencies must be understood in the context that antitrust officials often have significant bureaucratic discretion (Katzman, 1980; Weingast \& Moran, 1983). While Neven, Nuttal and Seabright (1993) argue that bureaucratic discretion provides space for special interest groups to capture antitrust policy, bureaucratic discretion also allows antitrust authorities to follow more informal—or even idiosyncratic_objectives. For instance, Neven, Nuttal and Seabright (1993) note that while the EU does not formally provide for an efficiency's defense, efficiencies do appear to have an informal impact on the merger review process. Boner and Krueger (1991) observe that antitrust authorities are often charged with non-competition related goals such as industrial, employment and regional policies, as well as balance of payments. In this vein, Levinsohn (1997) argues that a number of nations contain both formal and informal procedures that allow international competitive gains to be factored in merger reviews. Even the US — the paragon of strict antitrust policy—allows cartelization for 
export purposes under the Webb-Pomerene Act (U.S. GAO, 1973). Further, Kovacic and Shapiro (2000) — respectively an esteemed legal and economic scholar on antitrust issues — contend that declining economic productivity partly drove the lax US antitrust policy of the 1980's. Accordingly, the various antitrust institutional environments (particularly home antitrust institutions) appear at least partly amenable to factoring the international-competitive-effects of domestic merger activity.

In sum, it remains difficult to predict how industry trade balance will impact the tenor of domestic merger reviews from a theoretical standpoint. As a first-cut, it appears that an antitrust authority's formal criteria—national-welfare or consumer-surplus—might respectively suggest whether a net-exporter (net-importer) industry profile leads to more lenient (strict) or strict (lenient) merger policy. Yet once we open antitrust policy up to political economic determinants, the neat distinction between consumer-surplus and national-welfare driven merger policies muddles. Further, practicing lax merger reviews in order to shift international rents toward home producers does raise some similar caveats to the case of strategic trade policy (e.g., Branson \& Klevorick, 1990). Lastly, antitrust authorities often have significant bureaucratic discretion that might allow the net-export/net-import status of an industry to be considered during the merger review process. Consequently, the role played by an industry's trade balance on the tenor of domestic merger policy is ultimately an empirical question.

\section{Empirical Tests and Results}

Data cover US vetted mergers by industrial sector over the 1997-2001 period. The US represents one of the hardest cases in which to find international-competitive-effects impacting antitrust policy for a few reasons: the US has the longest antitrust tradition; the US has relatively strong antitrust institutions; and most importantly, the US has a very large domestic market in 
which foreign trade and foreign competition still play a relatively small role--i.e., the US is the anti-thesis of a small open economy. Accordingly, the US is probably the hardest case to find a net-exporter status contributing to lax antitrust or a net-exporter status contributing to strict antitrust. Consequently, if one finds international competitive dynamics impacting US merger policy, then it is a reasonable assumption to expect to find similar dynamics in other nationsnations more reliant on the role of foreign competition in protecting domestic consumers, and more reliant on foreign trade for industrial competitiveness.

The data are panel data covering sixty-five industrial sectors over the 1997-2001 period; thus, yielding a data set composed of 325 observations. Each panel consists of a two-digit industrial sector; for instance, 'Petroleum Refining' is one distinct panel consisting of five annual observations (1997-2001). While more specific industrial sector data would be desired (such as three or four digit data), US antitrust authorities only report data on antitrust activity at the twodigit level in the FTC and DOJ's combined 'Annual Report to Congress on Hart-Scott-Rodino Antitrust Enforcement'. ${ }^{1}$ Essentially, beyond constructing a data set on a merger-by-merger basis from the ground up, this is the best available data on merger enforcement in the US.

Unfortunately, the state of data on antitrust policy—both within and across nations_-is rather primitive (Horn \& Levinsohn, 2001).

Testing the propositions requires two principal variables: a measure of domestic antitrust scrutiny (the dependent variable), and a measure of industry trade-balance (the main explanatory variable). Beyond the two principal variables, additional variables - the number of intra-industry mergers, and the amount of merger activity taking place in the industry, the market share of the 50 largest firms, and the Herfindahl-Hirschmann-Index (HHI) for the 50 largest firms—are introduced in order to capture some of the structural conditions presented by each industry sector

\footnotetext{
${ }^{1}$ See www.ftc.gov/bc/hsr/hsrinfopub.htm for the 1997-2001 'Annual Reports to Congress'.
} 
and in order to make better causal inferences on the main explanatory variable. The following paragraphs explain the variable measures.

The dependent variable must capture the state of domestic antitrust scrutiny for a particular industry sector. I use the annual number of 'second-request-investigations' in a particular industry sector as indicative of the level of scrutiny given mergers in that sector (subsequently referred to as the Antitrust-Scrutiny variable). Second request investigations denote serious concerns on the part of US antitrust officials, who will consequently require more information from the merging firms, and more time to clear or contest the merger. This level of antitrust scrutiny is a pre-requisite for serious remedial measures: such as divestments and outright prevention. While a proportion of mergers will be cleared by the 'second-request' procedure, such investigations represent a degree of antitrust holdup for even the cleared mergers: as merging firms will be uncertain on the eventual outcome, required to divulge more information, and need to wait longer for clearance and completion of their intended strategy. Unsurprisingly, many merging parties will call off an intended merger when notified of a 'second-request' status. Further, the combined FTC/DOJ 'Annual Report to Congress on HartScott-Rodino Antitrust Enforcement' reveals this measure of US antitrust scrutiny. ${ }^{2}$

Testing the two competing propositions requires a measure of trade balance to examine whether greater trade-balances lead to stricter or more lenient antitrust-scrutiny for an industrial sector. The U.S. International Trade Commission reports annual data on the amount of exports and imports for two-digit industrial sectors: these measures allow the creation of this variable by simply subtracting imports from exports (subsequently referred to as the Trade-Balance variable). If proposition A is correct, then trade-balance will negatively affect antitrust-scrutiny: i.e., the more a particular industry is characterized by a net-exporter status, the more lenient are 
US antitrust authorities with regard to mergers. If proposition B is correct, then trade-balance will positively affect antitrust scrutiny: i.e., the more a particular industry is characterized by a net-exporter status, the more strict are US antitrust authorities with regard to mergers.

The list of explanatory variables also includes the number of intra-industry mergers within the two-digit industrial sector (subsequently referred to as the intra-industry-merger variable). Mergers that involve acquirers and targets from the same industrial sector will clearly merit more attention than mergers composed of pairs from separate industry sectors. Simply put, received wisdom suggests that conglomerate mergers merit the least amount of antitrust concern (though largest amount of stockholder concern). The combined FTC/DOJ Annual Report to Congress also reveals the number of merger transactions characterized as either two-digit or three-digit intra-industry transactions. I expect the Intra-Industry-Mergers variable to positively affect Antitrust-Scrutiny; thus, the more intra-industry-mergers in an industrial sector, the more antitrust officials should scrutinize the mergers and acquisitions taking place.

An additional explanatory variable includes the relative amount of merger activity taking place in an industrial sector. The already noted FTC/DOJ report provides data on the number of notified mergers per year per industrial sector; plus, the US Census Bureau provides data on the number of firms per industrial sector. ${ }^{3}$ These two measures allow the creation of what is subsequently referred to as the Industry-Merger-Activity variable: the number of notified transactions divided by the total number of firms in the two-digit industrial sector. IndustryMerger-Activity attempts to capture the degree to which the industry is subject to consolidation: with the assumption being that industries undergoing 'significant' consolidation merit more antitrust-scrutiny than industries undergoing low amounts of consolidation. I expect the Industry-

\footnotetext{
${ }^{2}$ Unfortunately, no other potential measures of antitrust scrutiny-such as number of prohibitions or remedial actions-are reported in the Annual Reports.

${ }^{3}$ See www.census.gov/econguide for information on the 'Core Business Statistics' for US industrial sectors.
} 
Merger-Activity variable to positively affect Antitrust-Scrutiny; thus, industries experiencing a relatively high degree of merger activity will experience higher degrees of antitrust scrutiny.

Finally, the U.S. Census Bureau (1997) provides more specific data—the market-share held by the largest 50 firms, and the HHI for the largest 50 firms—on the structural conditions for a subset of the industrial sectors (the sectors characterized as manufacturing). These two variables (subsequently referred to as TOP50-Market-Share and Top50-HHI) help better control for the structural conditions in which merger activity is embedded; thus, a sub-set of the regression models include them as control variables. Nevertheless, two opportunity costs are presented with the inclusion of these structural variables. First, the number of observations drops from 325 to 90 , as I was not able to obtain similar measures for non-manufacturing sectors. Second, the data derivates from the census of business activity and is thus reported only for 1997 and not on annual basis; accordingly, the range of empirical tests and model specifications (i.e., no fixed effects) are limited by the non-varying nature of these two variables over the 1997-2001 period.

\section{Econometric Issues}

Panel data require consideration of a number of econometric issues. This section considers and focuses on four issues: 1) the choice between fixed and random effects; 2) whether to include period effects; 3) non-linearity in the explanatory variables; 4) potential for multicollinearity

First, panel data usually require a choice between fixed-effects and random-effects. Fixed-effect models are called for when the panel-specific effects are unique and unrelated to other panels, while random-effect models are often employed when panel specific effects might be related amongst panels (Hsiao, 1986; Greene, 1990). While a series of Lagrange Multiplier 
and Hausman tests favor the choice of fixed-effects over random-effects (Greene, 1995), regression models using both specifications are reported in order to underscore the robustness of the results and — as alluded to above—-to handle the non-varying nature of the Top50-MarketShare and Top50-HHI variables.

Second, gradual changes have potentially occurred in the environment for merger \& acquisitions and merger-reviews over the 1997-2001 period. Changes--beyond those captured by the noted explanatory variables_-include an ebb-and-flow of overall merger activity (with 2000 representing the high point with 4926 reported transactions in the US), the increasingly international nature of antitrust, relative changes in antitrust budgets, and other developments that might impact the state of US merger policy. These changes can create time-specific data trends that affect causal inferences; thus, calling for the addition of period effects.

Third, an additional empirical concern is potential non-linearity in some of the explanatory variables, due in part to the left-censored nature of the dependent variable (antitrustscrutiny). A number of industry sectors were not subject to 'second-request-investigations' in particular years; thus, a number of observations are bunched at zero, yet of course, no negative values exist for antitrust-scrutiny. Consequently, Trade-Balance, Intra-Industry-Mergers, and Industry-Merger-Activity—are all likely to be subject to either increasing or decreasing returns. Accordingly, the squared term for all these variables is introduced into all the regression equations. Note that Top50-HHI and Top50-Market-Share might also be subject to non-linearity; yet, the non-varying nature of these measures over the 1997-2001 period prevents introducing a squared term due to collinearity.

Fourth, the relatively small number of observations (325-and 90 in the data subset) raises multi-collinearity concerns. Table 1 presents the correlation coefficients (and means) for all variables. It appears that three control variables-Industry-Merger-Activity, Top50-Market- 
Share, and Top50HHI-have some collinear tendencies: correlation coefficients above the 0.5 benchmark for notice. This does not overly surprise, as all three variables are included to capture some of the structural conditions within the industry sector. It is important to recall, however, that collinearity does not lead to unbiased estimates_-collinearity instead makes it more difficult to obtain significant coefficient estimates. No explanatory variables were dropped for collinearity concerns, as the main-explanatory variable (Trade-Balance) does not appear subject to collinearity; hence, there is no need to invite specification-bias.

$* * * * * * * * * * * * * * * * * * * *$

Put Table 1 here

$* * * * * * * * * * * * * * * * * * * *$

The regression models reported in the panel data regression results (Table 2) take the above econometric issues into account. While Regression \#1 reports the standard OLS regression, Regressions' \#2 \& \#3 incorporate a random effects specification and Regression \#4 a fixed-effects specification in order to control for any panel-specific effects. Additionally, Regression's \#2, \#3 \& \#4 incorporate a period effects specification in order to control for any time-specific effects. Further, the squared-term is introduced where possible in all the regression equations. While four different regression-models are presented in Table 2, Regression \#2 provides the most comprehensive coverage of the various econometric issues-though Regression \#4 might be the most rigorous regression model. Accordingly, Regression \#3 (a random-and-period effects model with a linear functional form) is represented here as follows:

$$
\begin{aligned}
& \text { Antitrust-Scrutiny } i t=b_{0}+{ }_{j=1} \Sigma^{2} b_{j} *(\text { Trade-Balance })^{j}{ }_{i t}+{ }_{j=1} \sum^{2} b_{j}+2 *(\text { Intra-Industry-Mergers })^{j}{ }_{i t}+{ }_{j=1} \Sigma^{2} \\
& b_{j}+4 *(\text { Industry-Merger-Activity })^{j}{ }_{i t}+b_{7} *(\text { Top50-Market-Share })_{i t}+b_{8} *(\text { Top50-HHI })_{i t}+\varepsilon_{i t}+u_{i}+w_{t}
\end{aligned}
$$


where $\mathrm{i}$ indexes the 65 industrial sectors, $\mathrm{t}$ indexes time, $\mathrm{j}$ allows for convenient expression of a non-linear variable, $\mathrm{u}_{\mathrm{i}}$ represents the panel specific effect, and $\mathrm{wt}$ captures the period specific effect.

\section{Results and Interpretation}

Table 2 presents the empirical results for four regression models. All four regression equations indicate moderate model-specification: with R-squares: ranging from .15 in Regression \#2 to .80 in Regression \#4. More importantly, the four models generate consistent results for the coefficient estimates - virtually all the common variables point in the same direction. Due to the general consistency of results across the regression models, the following analysis and interpretation discusses the results as a whole with a variable-by-variable approach.

The Trade-Balance variable and the squared term for Trade Balance are instrumental in testing propositions' A \& B. While both Trade-Balance and its squared term indicate positive directions in all four regression-models, both variables are only significant (at the 5-\% level) in Regression \#1. Accordingly, the empirical evidence tentatively supports Proposition B over Proposition A, as more positive trade-balances lead to more antitrust-scrutiny--and at an increasing rate. Nevertheless, it should be reiterated that the reported tests are far from conclusive, as statistical significance is not robust.

The Intra-Industry-Mergers variable and the squared term for that variable are included to make better causal inference on the above Trade-Balance variable. We expected and found a positive sign for the Intra-Industry-Mergers variable, as mergers between acquirers and targets from the same industry should merit further antitrust scrutiny by regulators. While the coefficient estimate for Intra-Industry-Mergers is positive in all four regression-models, it is only significant (at the 10-\% level) in Regression \#3. Further, the squared term for Intra-Industry-Mergers 
indicates a positive sign in Regressions' \#1 \& \#2 (data based on the manufacturing industrial sectors), but negative in Regressions' \#3 \& \#4 (data based on all industrial sectors); nevertheless, the squared-term coefficient estimate is not significant in any of the regression models.

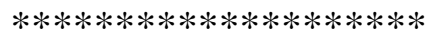

Put Table 2 here

$* * * * * * * * * * * * * * * * * * * *$

The Industry-Merger-Activity variable appears to be the most robust variable in the regression results. The expectation was for greater amounts of merger activity in an industry (i.e., the number of notified mergers divided by the number of firms in that industry) to elicit higher degrees of antitrust-scrutiny on the part of regulators. This appears to be born out as the coefficient estimate for this variable is positive and significant in all four regression models: i.e., the more an industry is characterized by intense merger activity relative to the amount of firms, the more antitrust officials scrutinize mergers in that industry. In essence, this result conforms to Ghosal and Gallo's (2001) finding that the US DOJ mainly acts as an antitrust law enforcement agency (essentially a 'policeman'). Further, the squared term for Industry-Merger-Activity is negative in all the regression equations and significant in three of the four models; accordingly, the 'policeman' role is moderated at higher levels of merger activity in an industrial sector.

Lastly, the two additional variables-Top50-Market-Share and Top50-HHI-included only in Regressions' \#1 \& \#2 to better control for the structural conditions in the industry sector yield mixed results. First off, the coefficient estimate for Top50-Market-Share exhibits the expected positive sign, yet the coefficient estimate for Top50-HHI exhibits a negative sign. Nevertheless, neither variable exhibits statistical significance.

In sum, the empirical results appear to tentatively support proposition B over proposition A. There appears to be scant evidence in support of the contention that US antitrust authorities 
practice more lenient merger policy in industrial sectors characterized by larger trade balances. Instead, US antitrust authorities appear to practice stricter merger policy when industrial sectors are characterized by larger trade balances_-albeit the statistical significance of this result is not robust.

\section{Conclusion}

The existing literature on merger policy in an open-economy setting presents two competing rationales on how sectoral trade balances might impact the tenor of domestic merger policy. Some scholars (Barros \& Cabral, 1994; Levinsohn, 1997; Sorgard, 1997; Head \& Ries, 1997; Yano, 2001; and Zhang \& Chen, 2002) suggest that positive trade balances lead to more lenient merger reviews, as a nation's welfare is enhanced by the producer gains reaped in foreign markets. Other scholars (Landes \& Posner, 1981; Ghosal, 2002) suggest that positive trade balances lead to stricter merger reviews, as consumer welfare is increasingly endangered when imports do not represent a disciplinary threat to domestic anti-competitive practices.

Consequently, the role of trade-balance on domestic merger policy appears to reduce to the objective function (national-welfare or consumer-surplus) of a regulator. However, such a reduction is made more problematic once one recognizes that merger-reviews are subject to political economic dynamics, the dangers of using 'strategic' merger policy, and the bureaucratic discretion held by most antitrust authorities.

This paper accordingly takes an empirical approach to shedding light on how trade balance might impact the tenor of domestic merger policy. Empirical tests based on a comprehensive panel data set_covering US merger policy at the two-digit SIC code level over the 1997-2001 period — generate two findings. First, scant evidence exists to support US antitrust regulators practicing lenient merger reviews when an industrial sector is subject to positive trade 
balances. Simply put, US antitrust authorities do not appear to be practicing any form of beggarthy-neighbor merger policy. Second, tentative evidence does support US antitrust regulators practicing stricter merger reviews when an industrial sector is subject to larger trade balances. Consequently, the stated objective function (consumer-surplus) of US antitrust policy does appear to guide merger reviews even when the lure of international competitive gains is introduced. In sum, the US does not appear to be engaging in 'strategic' merger policy, and consumer-welfare remains the dominant criterion when US merger policy is analyzed in an openeconomy setting.

The results here present some interesting extensions and implications. One implication pertains to the ongoing WTO talks where harmonization of antitrust polices is being considered. One rationale behind harmonization is that it would curb national antitrust authorities from engaging in lax merger reviews when the majority of the merger's deleterious effects are reaped in foreign markets. A number of scholars (Bliss, 1997; Klevorick, 1997) have debated the raceto-the-bottom potential for merger policy in a globalized world. The evidence here, however, suggests that such concerns are unfounded when it comes to US merger policy. Which leads to an obvious extension of this work: it would be informative to run similar empirical tests with medium-sized and small-sized nationals (data limitations aside), as the US is the antithesis of a small open economy. The lure of international competitive gains may prove more potent in relatively smaller nations. As already noted, a casual read through international reports (e.g., OECD, 1998) suggests that many nations do consider the international competitive gains from allowing domestic merger activity. 


\section{References}

Abbot, A. 1985. Foreign competition and relevant market definition under the Department of Justice's Merger Guidelines. The Antitrust Bulletin, Summer: 299-336.

Barros, P.P. \& Cabral L. 1994. Merger Policy in Open Economies. European Economic Review, 38: 1041-1055.

Bliss, C. 1997. Trade and Competition Control. In J.N. Bhagwati \& R.E. Hudec (Eds.) Fair Trade and Harmonization: Prerequisites for Free Trade?. Cambridge MA: The MIT Press.

Boner, R. A. \& Krueger, R. 1991. The Basics of Antitrust Policy: A Review of Ten Nations and the European Communities. World Bank Technical Papers, No. 160, Washington DC: The World Bank.

Branson, W.H. \& Klevorick, A.K. 1990. Strategic Behavior and Trade Policy. In P.R. Krugman (Ed.) Strategic Trade Policy and the New International Economics. Cambridge MA: MIT Press.

Clougherty, J.A. 2002. A Political Economic Approach to the Domestic Airline Merger Phenomenon. Journal of Transport Economics and Policy, 36(1): 27-48.

Coate, M.B., Higgins, R.S. \& McChesney F.S., 1990. Bureaucracy and Politics in FTC Merger Challenges, Journal of Law and Economics, 33: 463-482.

Dixit, A.K. and Grossman, G.M. (1984) Targeted Export Promotion with Several Oligopolistic Industries. Journal of International Economics, 21, 23-49.

Eaton, J. and Grossman, G.M. (1986) Optimal Trade and Industrial Policy under Oligopoly. Quarterly Journal of Economics, 101, 383-406.

Farrell, J. \& Shapiro, C. 1990. Horizontal Mergers: An Equilibrium Analysis. American Economic Review, 80(1): 107-126.

Faith, R.L., Leavens, D.R. \& Tollison, R.D. 1982. Antitrust Pork Barrel. Journal of Law and Economics, 25: 329-42.

Fisher, F.M. 1987. Horizontal Mergers: Triage and Treatment. Journal of Economic Perspectives, 1: 23-40.

Ghosal, V. \& J. Gallo 2002. The Cyclical Behavior of the Department of Justice's Antitrust Enforcement Activity. International Journal of Industrial Organization, 19: 27-54.

Ghosal, V. 2002. Potential Foreign Competition in U.S. Manufacturing. International Journal of Industrial Organization, 20: 1461-1489.

Greene, William H. 1990. Econometric Analysis. New York: Macmillan. 
Greene, William H. 1995. LIMDEP Version 7.0. New York: Econometric Software, Inc.

Grossman, G.M. 1990. Strategic Export Promotion: A Critique. In P.R. Krugman (Ed.) Strategic Trade Policy and the New International Economics. Cambridge MA: MIT Press.

Head, K. \& Ries, J. 1997. International mergers and welfare under decentralized competition policy. Canadian Journal of Economics, 30(4b): 1104-1123.

Horn, H. \& Levinsohn, J. 2001. Merger Policies and Trade Liberalization. The Economic Journal, 111: 244-276.

Hsiao, C., 1986. Analysis of Panel Data. Cambridge UK: Cambridge University Press. Katzmann, R.A. 1980, Regulatory Bureaucracy: The Federal Trade Commission and Antitrust Policy, Cambridge MA: The MIT Press.

Klevorick, A.K. 1997. Reflections on the Race to the Bottom. In J.N. Bhagwati \& R.E. Hudec (Eds.) Fair Trade and Harmonization: Prerequisites for Free Trade?. Cambridge MA: The MIT Press.

Kovacic, W.E. \& Shapiro C. 2000. Antitrust Policy: A Century of Economic and Legal Thinking. Journal of Economic Perspectives, 14(1): 43-60.

Krugman, P.R. 1984. Import Protection as Export Promotion: International Competition in the Presence of Oligopoly and Economies of Scale. In H. Kierzkowski, editor, Monopolistic competition and international trade. 180-193. Oxford, UK: Clarendon.

Landes, W. \& Posner, R. 1981. Market power in antitrust cases. Harvard Law Review, 94: 937996.

Levinsohn, J. 1997. Competition Policy and International Trade. In J.N. Bhagwati \& R.E. Hudec (Eds.) Fair Trade and Harmonization: Prerequisites for Free Trade?. Cambridge MA: The MIT Press.

Mavrodis, P.C. \& Neven, D.J. 2001. From the White Paper to the Proposal for a Council Regulation: How to Treat the New Kids on the Block. Legal Issues of Economic Integration, 28(2): 151-171.

Melamed, A.D. 2000. Promoting Sound Antitrust Enforcement in the Global Economy. Address by the Acting Assistant Attorney General, Antitrust Division, U.S. Department of Justice. Before the Fordham Corporate Law Insititute: $27^{\text {th }}$ Annual Conference on International Antitrut Law and Policy. On October 19, 2000 in New York, NY.

Monti, Mario, 2002. Competition: Europe's merger monitor. The Economist. November, 9: 7172.

Neven, D.J. \& Roller, L.-H. 2000a. Institution Design: The Allocation of jurisdiction in international antitrust. European Economic Review. 44: 845-855. 
Neven, D.J. \& Roller, L.-H. 2000b. The Scope of Conflict in International Merger Control. CEPR (Centre for Economic Policy Research) Policy Paper, No. 2621.

Neven, D.J., Nuttal R., \& Seabright, P. 1993. Merger in Daylight: the Economics and Politics of EC Merger Control. CEPR: London.

Neven, D.J.. Papandropoulos, P. \& Seabright, P. 1998. Trawling for Minnows: European

Competition Policy and Agreements Between Firms, London: CEPR.

OECD, 1998. Competition Policy in OECD Countries. Paris: OECD.

Ordover, J. \& Willig, R. 1983. The 1982 Department of Justice Merger Guidelines: An Economic Assesment, California Law Review.

Pittman, R. 1977. Market Structure and Campaign Contributions. Public Choice, 31:37-58.

Richardson, M. 1999. Trade and competition policies: concordia discors?. Oxford Economic Papers, 51(4): 649-664.

Sorgard, L. 1997. Domestic merger policy in an international oligopoly: The Nordic market for electricity. Energy Economics, 19: 239-53.

U.S. Census Bureau. 1997. Concentration Ratios in Manufacturing. Report No. EC97M31S-CR, Washington DC: U.S. Census Bureau.

U.S. DOJ. 1997. Horizontal Merger Guidelines. Washington DC: U.S. Department of JusticeAntitrust Division.

U.S. GAO. 1973. Clarifying Webb-Pomerene Act Needed to Help Increase U.S. Exports. Washington DC: U.S. General Accounting Office.

Vandenbussche, Hylke, 2000. Trade Policy Versus Competition Policy: Substitutes or Complements?. De Economist, 148(5): 625-642.

Weingast, B.R. \& Moran, M.J. 1983, Bureaucratic discretion or congressional control?: Regulatory policy making by the Federal Trade Commission, Journal of Political Economy, 91: 765-800.

White, L.J. 1987. Antitrust and Merger Policy: A Review and Critique. Journal of Economic Perspectives, 1: 13-22.

Williamson, O.E., 1968. Economies as an Antitrust Defense: The Welfare Tradeoffs. American Economic Review, 58: 18-36.

Yano, M. 2001. Trade Imbalance and Domestic Market Competition Policy. International Economic Review, 42(3): 729-750. 
Zhang, A. \& Chen, H. 2002. Horizontal Mergers in a Liberalizing World Economy. Pacific Economic Review, 7(2): 1-18. 


\section{Table 1: Correlation Coefficients \& Means for All Variables}

\begin{tabular}{|c|c|c|c|c|c|c|}
\hline & $\begin{array}{l}\text { Antitrust- } \\
\text { Scrutiny }\end{array}$ & $\begin{array}{l}\text { Trade- } \\
\text { Balance }\end{array}$ & $\begin{array}{l}\text { Intra- } \\
\text { Industry- } \\
\text { Mergers }\end{array}$ & $\begin{array}{l}\text { Industry- } \\
\text { Merger- } \\
\text { Activity }\end{array}$ & $\begin{array}{l}\text { Top50- } \\
\text { Market-Share }\end{array}$ & Top50-HHI \\
\hline Mean & 1.59 & -4691 & 30.24 & 0.00256 & 53.29 & 202.48 \\
\hline $\begin{array}{l}\text { Antitrust- } \\
\text { Scrutiny }\end{array}$ & 1.0 & & & & & \\
\hline $\begin{array}{l}\text { Trade- } \\
\text { Balance }\end{array}$ & .00134 & 1.0 & & & & \\
\hline $\begin{array}{l}\text { Intra- } \\
\text { Industry- } \\
\text { Mergers }\end{array}$ & 0.6001 & 0.06105 & 1.0 & & & \\
\hline $\begin{array}{l}\text { Industry- } \\
\text { Merger- } \\
\text { Activity }\end{array}$ & 0.30326 & -0.02284 & 0.14488 & 1.0 & & \\
\hline $\begin{array}{l}\text { Top50- } \\
\text { Market-Share }\end{array}$ & 0.04622 & -0.00714 & -0.18238 & 0.49971 & 1.0 & \\
\hline Top50-HHI & -0.06439 & -0.20121 & -0.18944 & 0.57843 & 0.81758 & 1.0 \\
\hline
\end{tabular}




\begin{tabular}{|c|c|c|c|c|}
\hline \multicolumn{5}{|c|}{$\begin{array}{l}\text { Table 2: Panel Data Regression Result } \\
\text { Dependent Variable: Antitrust-Scrutiny }\end{array}$} \\
\hline & Regression Mod & Is Based on $\mathrm{N}=90$ & Regression Mod & s Based on $\mathrm{N}=325$ \\
\hline & $\begin{array}{l}\text { Regression \#1: } \\
\text { OLS Estimation }\end{array}$ & $\begin{array}{l}\text { Regression \#2: } \\
\text { Two-Way Random- } \\
\text { Effects Estimation }\end{array}$ & $\begin{array}{l}\text { Regression \#3: } \\
\text { Two-Way } \\
\text { Random-Effects } \\
\text { Estimation }\end{array}$ & $\begin{array}{l}\text { Regression \#4: } \\
\text { Two-Way Fixed- } \\
\text { Effects } \\
\text { Estimation }\end{array}$ \\
\hline \multicolumn{5}{|l|}{ Explanatory Variables } \\
\hline Trade-Balance & $\begin{array}{l}0.000084 * * \\
(2.57)\end{array}$ & $\begin{array}{l}0.000057 \\
(1.38)\end{array}$ & $\begin{array}{c}0.000043 \\
(1.57)\end{array}$ & $\begin{array}{c}0.00007 \\
(1.43)\end{array}$ \\
\hline$(\text { Trade-Balance })^{2}$ & $\begin{array}{c}1.31 \mathrm{E}-9 * * \\
(2.52)\end{array}$ & $\begin{array}{l}2.997 \mathrm{E}-10 \\
(0.57)\end{array}$ & $\begin{array}{l}4.59 \mathrm{E}-10 \\
\quad(1.57)\end{array}$ & $\begin{array}{l}5.27 \mathrm{E}-10 \\
\quad(1.30)\end{array}$ \\
\hline $\begin{array}{l}\text { Intra-Industry- } \\
\text { Mergers }\end{array}$ & $\begin{array}{c}0.02 \\
(0.79)\end{array}$ & $\begin{array}{l}0.003 \\
(0.14)\end{array}$ & $\begin{array}{l}0.016 * * * \\
(3.03)\end{array}$ & $\begin{array}{l}0.012 \\
(1.61)\end{array}$ \\
\hline $\begin{array}{l}\text { (Intra-Industry- } \\
\text { Mergers) }^{2}\end{array}$ & $\begin{array}{c}0.000069 \\
(0.354)\end{array}$ & $\begin{array}{c}0.000015 \\
(0.09)\end{array}$ & $\begin{array}{c}-0.00000955 \\
(-0.51)\end{array}$ & $\begin{array}{c}-0.0000078 \\
(-0.34)\end{array}$ \\
\hline $\begin{array}{l}\text { Industry-Merger- } \\
\text { Activity }\end{array}$ & $\begin{array}{c}252.83 * \\
(1.90)\end{array}$ & $\begin{array}{c}244.47 * \\
(1.94)\end{array}$ & $\begin{array}{l}314.63 * * * \\
\quad(4.40)\end{array}$ & $\begin{array}{l}210.74 * * \\
(2.06)\end{array}$ \\
\hline $\begin{array}{l}\text { (Industry-Merger- } \\
\text { Activity) }\end{array}$ & $\begin{array}{c}-6260.87 * \\
(-1.92)\end{array}$ & $\begin{array}{c}-4712.91 * \\
(-1.70)\end{array}$ & $\begin{array}{c}-6232.44 * * * \\
(-3.40)\end{array}$ & $\begin{array}{c}-3426.88 \\
(-1.50)\end{array}$ \\
\hline Top50-Market-Share & $\begin{array}{c}0.027 \\
(1.002)\end{array}$ & $\begin{array}{l}0.011 \\
(0.23)\end{array}$ & & \\
\hline Top50-HHI & $\begin{array}{l}-0.0034 \\
(-1.29)\end{array}$ & $\begin{array}{r}-0.0027 \\
(-0.63)\end{array}$ & & \\
\hline Constant & $\begin{array}{c}0.203 \\
(0.165)\end{array}$ & $\begin{array}{l}1.76 \\
(0.85)\end{array}$ & $\begin{array}{l}0.61 * * \\
(2.08)\end{array}$ & $\begin{array}{c}0.21 \\
(0.30)\end{array}$ \\
\hline $\mathrm{R}$-squared & .42 & .15 & .20 & .80 \\
\hline()$=$ T-stat & $\begin{array}{l}* * *=1 \% \\
\text { Signif. }\end{array}$ & $* *=5 \%$ Signif. & $*=10 \%$ Signif. & \\
\hline
\end{tabular}


Bücher des Forschungsschwerpunkts Markt und politische Ökonomie

Books of the Research Area Markets and Political Economy

Sebastian Kessing

Essays on Employment Protection

2003, Freie Universität Berlin,

http://www.diss.fu-berlin.de/2003/202

Daniel Krähmer

On Learning and Information in Markets and

Organizations

2003, Shaker Verlag

Andreas Stephan

Essays on the Contribution of Public Infrastructure to Private: Production and its Political

Economy

2002, dissertation.de

Hans Mewis

Essays on Herd Behavior and Strategic

Delegation

2001, Shaker Verlag

Andreas Moerke

Organisationslernen über Netzwerke - Die personellen Verflechtungen von

Führungsgremien japanischer

Aktiengesellschaften

2001, Deutscher Universitäts-Verlag

Silke Neubauer

Multimarket Contact and Organizational Design

2001, Deutscher Universitäts-Verlag

Lars-Hendrik Röller, Christian Wey (Eds.)

Die Soziale Marktwirtschaft in der neuen

Weltwirtschaft, WZB Jahrbuch 2001

2001, edition sigma

Michael Tröge

Competition in Credit Markets: A Theoretic

Analysis

2001, Deutscher Universitäts-Verlag

Tobias Miarka

Financial Intermediation and Deregulation:

A Critical Analysis of Japanese Bank-Firm-

Relationships

2000, Physica-Verlag

Rita Zobel

Beschäftigungsveränderungen und organisationales Lernen in japanischen Industriengesellschaften

2000, Humboldt-Universität zu Berlin http://dochost.rz.hu-berlin.de/dissertationen/zobelrita-2000-06-19
Jos Jansen

Essays on Incentives in Regulation and

Innovation

2000, Tilburg University

Ralph Siebert

Innovation, Research Joint Ventures, and Multiproduct Competition

2000, Humboldt-Universität zu Berlin

http://dochost.rz.hu-berlin.de/dissertationen/siebertralph-2000-03-23/

Damien J. Neven, Lars-Hendrik Röller (Eds.)

The Political Economy of Industrial Policy in

Europe and the Member States

2000, edition sigma

Jianping Yang

Bankbeziehungen deutscher Unternehmen: Investitionsverhalten und Risikoanalyse

2000, Deutscher Universitäts-Verlag

Christoph Schenk

Cooperation between Competitors -

Subcontracting and the Influence of Information, Production and Capacity on Market Structure and Competition

1999, Humboldt-Universität zu Berlin

http://dochost.rz.hu-berlin.de/dissertationen/schenkchristoph-1999-11-16

Horst Albach, Ulrike Görtzen, Rita Zobel (Eds.)

Information Processing as a Competitive

Advantage of Japanese Firms

1999, edition sigma

Dieter Köster

Wettbewerb in Netzproduktmärkten

1999, Deutscher Universitäts-Verlag

Christian Wey

Marktorganisation durch Standardisierung: Ein

Beitrag zur Neuen Institutionenökonomik des

Marktes

1999, edition sigma

Horst Albach, Meinolf Dierkes, Ariane Berthoin Antal, Kristina Vaillant (Hg.)

Organisationslernen - institutionelle und

kulturelle Dimensionen

WZB-Jahrbuch 1998

1998, edition sigma 
Lars Bergman, Chris Doyle, Jordi Gual, Lars Hultkrantz, Damien Neven, Lars-Hendrik Röller, Leonard Waverman

Europe's Network Industries: Conflicting Priorities - Telecommunications

Monitoring European Deregulation 1

1998, Centre for Economic Policy Research

Manfred Fleischer

The Inefficiency Trap

Strategy Failure in the

German Machine Tool Industry

1997, edition sigma
Christian Göseke

Information Gathering and Dissemination

The Contribution of JETRO to

Japanese Competitiveness

1997, Deutscher Universitäts-Verlag 
Fredrik Andersson

Kai A. Konrad

Lars-Hendrik Röller

Christian Wey

Talat Mahmood Klaus Schömann

Talat Mahmood Klaus Schömann

Jos Jansen

Jos Jansen

Günter Franke Harris Schlesinger Richard C. Stapleton

Tomaso Duso

Johan Lagerlöf

Paul Heidhues

Olivier Cadot Lars-Hendrik Röller Andreas Stephan

Justus Haucap

Christian Wey

Heidrun C. Hoppe Emre Ozdenoren

Rainer Nitsche

Daniel Krähmer

J. Peter Murmann

Kai A. Konrad

Robert Nuscheler

Fredrik Andersson Kai A. Konrad
Human Capital Investment and Globalization in Extortionary States

Merger Control in the New Economy

Die Determinanten der Mirgrationsentscheidung von IT-Hochschulabsolventen aus Pakistan Empirische Befunde zur Ausgestaltung der deutschen „Green Card“

The Determinants of the Migration Decision of ITgraduates from Pakistan: Empirical Evidence for the Design of a German "Green Card"

The Effects of Disclosure Regulation on Innovative Firms: Common Values

The Effects of Disclosure Regulation on Innovative Firms: Private Values

Multiplicative Background Risk

On the Politics of the Regulatory Reform:

Econometric Evidence from the OECD Countries

On the Desirability of an Efficiency Defense in

Merger Control

Contribution to Productivity or Pork Barrel? The Two Faces of Infrastructure Investment

Unionization Structures and Firms' Incentives for Productivity Enhancing Investments

Intermediation in Innovation

On the Effectiveness of Anti-Predation Rules

Entry and Experimentation in

Oligopolistic Markets for Experience Goods

The Coevolution of Industries and National Institutions: Theory and Evidence

Terrorism and the State

Physician Reimbursement, Time-Consistency and the Quality of Care

Taxation and Education Investment in the Tertiary Sector
FS IV $02-06$

FS IV $02-11$

FS IV $02-12$

FS IV $02-15$

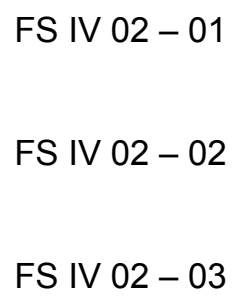

FS IV $02-02$ 
Jan Boone

Kai A. Konrad

Helmut Bester

Kai A. Konrad

Kjell Erik Lommerud Bjørn Sandvik

Odd Rune Straume

Steffen Huck Vicki Knoblauch Wieland Müller

Ralph Siebert

Jürgen Bracht

Saul Lach

Eyal Winter

Steffen Huck

Kai A. Konrad

Daniel Krähmer

Thomas Knaus

Robert Nuscheler

Kurt R. Brekke

Robert Nuscheler

Odd Rune Straume

Kai A. Konrad

Sebastian Kessing

Sebastian Kessing

Michal Grajek

Robert M. Adams Lars-Hendrik Röller

Robin C. Sickles

Tomaso Duso

Damien J. Neven Lars-Hendrik Röller

Tomaso Duso Astrid Jung
'Be nice, unless it pays to fight': A New Theory of

Price Determination with Implications for

Competition Policy

Altruism and Envy in Contests:

An Evolutionarily Stable Symbiosis

Delay in Contests

Good Jobs, Bad Jobs and Redistribution

On the Profitability of Collusion in Location Games

Learning by Doing and Multiproduction Effects over the Life Cycle: Evidence from the

Semiconductor Industry

Modeling Oligopolistic Price Adjustment in Micro

Level Panel Data

Strategic Trade Policy and the Home Bias in Firm

Ownership Structure

Delegation versus Authority

Incomplete Risk Adjustment and Adverse

Selection in the German Public Health Insurance System

Quality and Location Choices under Price

Regulation

Inverse Campaigning

A Note on the Determinants of Labour Share Movements

Employment Protection and Product Market Competition

Identification of Network Externalities in Markets for Non-Durables

Market Power in Outputs and Inputs: An Empirical Application to Banking

The Political Economy of European Merger Control: Evidence using Stock Market Data

Market Conduct and Endogenous Lobbying: Evidence from the U.S. Mobile Telecommunications Industry
FS IV $02-20$

FS IV $02-21$

FS IV $02-22$

FS IV $02-28$

FS IV $02-29$

FS IV $02-18$

FS IV $02-19$

FS IV $02-23$

FS IV $02-24$

FS IV $02-25$

FS IV $02-26$

FS IV $02-27$

FS IV $02-30$

FS IV $02-31$

FS IV $02-32$

FS IV $02-33$

FS IV $02-34$

FS IV $02-35$ 
Annette Boom

Kai A. Konrad Wolfram F. Richter

Stergios Skaperdas

Johan Lagerlöf

Roman Inderst

Christian Wey

Sebastian Kessing

Robert Nuscheler

Lars Frisell

Paul Heidhues Nicolas Melissas

Pablo Beramendi

Daniel Krähmer

Ralph Siebert

Vivek Ghosal

Vivek Ghosal

Andreas Blume

Paul Heidhues

Sebastian Kessing

Tomaso Duso Astrid Jung

Thomas R. Cusack Pablo Beramendi

Kjell Erik Lommerud Frode Meland Odd Rune Straume
Investments in Electricity Generating Capacity under Different Market Structures and with Endogenously Fixed Demand

Zur Berücksichtigung von Kindern bei umlagefinanzierter Alterssicherung

Restraining the Genuine Homo Economicus: Why the Economy cannot be divorced from its Governance

Insisting on a Non-Negative Price: Oligopoly, Uncertainty, Welfare, and Multiple Equilibria

Buyer Power and Supplier Incentives

Monopoly Pricing with Negative Network Effects: the Case of Vaccines

The Breakdown of Authority

Equilibria in a Dynamic Global Game: The Role of Cohort Effects

Political Institutions and Income Inequality: The Case of Decentralization

Learning and Self-Confidence in Contests

The Introduction of New Product Qualities by Incumbent Firms: Market Proliferation versus Cannibalization

Impact of Uncertainty and Sunk Costs on Firm Survival and Industry Dynamics

Endemic Volatility of Firms and Establishments: Are Real Options Effects Important?

Private Monitoring in Auctions

Delay in Joint Projects

Product Market Competition and Lobbying

Coordination in the U.S. Mobile

Telecommunications Industry

Taxing Work: Some Political and Economic Aspects of Labor Income Taxation

Globalisation and Union Opposition to Technological Change
SP II $2003-05$

SP || 2003-07

SP || 2003 - 14

SP || $2003-15$

SP || $2003-01$

SP II 2003-02

SP || $2003-03$

SP || $2003-06$

SP II 2003-08

SP || 2003-09

SP II $2003-10$

SP || $2003-11$

SP || 2003- 12

SP II $2003-13$

SP || 2003- 16

SP || $2003-17$

SP || $2003-18$ 
Bei Ihren Bestellungen von WZB-Papers schicken

Sie bitte unbedingt einen an Sie adressierten Auf-

kleber mit sowie je paper eine Briefmarke im Wert

von 0,51 Euro oder einen "Coupon Reponse Inter-

national " (für Besteller aus dem Ausland)
Please send a self addressed label and postage stamps in the amount of 0.51 Euro or a "CouponReponse International" (if you are ordering from outside Germany) for each WZB-paper requested

Absender / Return Address:

Wissenschaftszentrum Berlin

für Sozialforschung

Presse- und informationsreferat

Reichpietschufer 50

D-10785 Berlin-Tiergarten

Hiermit bestelle ich folgende(s)

Discussion paper(s):

Please send me the following Discussion paper(s):

Bestell-Nr. / Order no.

Autor/in, Kurztitel /Author(s) / Title(s) in brief 